\title{
Empowerment of Group Role to Develop Learning Independency of Farmers in Farming Business (Lifelong Learning Case of Farmers Group in Pagerwangi Village Lembang Subregency West Bandung Regency)
}

\author{
Nunu Heryanto
}

\begin{abstract}
Learning independency is a condition that can be grown through the provision of power/strength (empowerment); by strengthening the role of group dynamic components in dynamic interaction in group. The problem is: "how is the influence of group role empowerment to learning independency development of farmers in farming business". The research was done in Pagerwangi Village with research subject farmers group members. Method of analytical descriptive is proved: (1) Empowerment of group dynamic components supports and affects empowerment programme, (2) Empowerment of group dynamic components affects farmers' learning independency, (3) Provision of power/strength to farmers has strong and direct correlation with learning independency development of farmers, (4) Empowerment with learning dynamic, effort dynamic, and teamwork dynamic subvariable is proved has strong correlation and significant influence to learning independency development of farmers in farming business partially and simultaneously.
\end{abstract}

Keywords - Group Dynamic, Empowerment, and Learning Independency.

\section{INTRODUCTION}

Economy openness as a result of globalization creates condition that demand high level of efficiency, challenge, and competitiveness towards various Indonesian commodities from foreign countries commodities. People demanded not only to orient products that needed by market but also to create market and to be able to compete with foreign countries agriculture product in quality, productivity, and efficiency in domestic, regional, and international market. Bungaran Saragih (2010:3) said that causal factors in declining of farming business production are mental attitude and absence of learning independency, poor access to natural and other economical resources, low mastery of productive resources, and low quality of human resources. According to Soewardi (1987: 17), farmer who has narrow field and limited choice on government programme package will orient to waiting-for-instruction attitude, this attitude causes them to lose power in developing independency and further demonstrates farmer's dependence on external power. Margono Slamet (1995:28) stated that this dependency not only in getting information/learning, but also in decision making. Margono Slamet (1995:31) explained further that the root of problem lied in less socialization of lifelong learning independency facilitation, Ace Suryadi (2014:17) confirmed that implementation of lifelong learning in few contexts is often unclear. Whereas lifelong learning facilitation and socialization are very strategic as information update and adaptability counterweight to continuous change, so that in turn it becomes learners' commitment to continue learning to achieve goal; and according to Joni Rahmat (2013:43), it is called autonomous learners.

Learning independency means manifestation of people's ability to utilize their own potency in meeting their need (Hubeis, 1992:47). Margono Slamet (2005:32) emphasized that in order to grow and develop learning independency, people need to be directed, so that people with their own power and ability teamed to achieve all their need. Empowerment of member in farmers group is considered important because in farming development, farmers are development resource who play key role in developing farming business. Bryant dan White (1982, in Nunu Heryanto, 2016:122) stated that empowerment means (1) provision of opportunity to freely choose various alternatives according to their level of awareness, ability, and desire, and (2) provision of learning opportunity from their success and failure in responding to changes, so that they will be able to control their future.

The abundance of human and natural resources in agriculture sector can be used as comparative advantage in the past, but for now and in the future, it is not enough, it also must be accompanied by high quality and competitive advantage. Mosher, Leagans and Loomis (1971, in Margono Slamet, 200:22) confirmed that the fundamental of agricultural development is change in attitude and behaviour of farmers through counseling, so that they can develop their farming business. Nunu Heryanto (2016:285) stated that farmers must continue the lifelong learning in order to be able and become smart to take business opportunities and build teamwork to increase production and improve their quality of life. Kartasapoetra (1988:25) said that agricultural counseling is a non-formal education system to change behaviour of farmers 
and their family so that they know, want, and able to solve their problem in increasing their income from farming business and life status.

Ace Suryadi (2014:16), Joni Rahmat (2013:46) and Barker et al. (1987:98) stated that lifelong learning action can be done through institution or group empowerment which embodies community development. According to Abbas (1995:67), farmers group has potency to play roles as: (1) vehicle of learning, (2) production unit of farming business, and (3) vehicle of teamwork to solve various challenges and obstacles. K. Subrata (2000:4) stated that group acts as interactiveeducative media of mutual learning between group members so that adjustive change happened. Kincaid and Yum (1976:12) showed advantage of teamwork in group that is faster work. John Wong (1979:11) gave few reasons that support the need of group empowerment in farming business management, that are to overcome institutional obstacles, to facilitate farmer's continuous learning, to utilize irrigation system more optimally, to utilize goods and capital, and to control ecosystem. From his experience, Adjid (1981:5) told the history of rice sulf-sufficiency is a proof that farmers group functions as facility creates social psychological condition that encourages growth of sensitivity, initiative, creativity and innovative power, motivation, solidarity, responsibility and participation of members to respond every problem that arises in the implementation of farming business.

Research problems in detail are (1) How are correlation of group dynamic variable with empowerment and learning independency variable and correlation of empowerment variable and learning independency of farmers in farming business variable, (2) how greater are the influence of group dynamic variable to empowerment variable and empowerment variable to learning independency development of farmers in farming business, (3) how are correlation between empowerment subvariables that are learning, effort and teamwork dynamic and independency development of farmers in farming business, and (4) how greater is the influence of each empowerment subvariable to learning independency development of farmers in farming business partially and simultaneously.

\section{RESEARCH PROTOCOL}

Research was conducted in Pagerwangi Village in 2015 with research subject is farmers who joined in four farmers groups with total member 75 farmers and sampling withdrawal with random technique is calculated by Slovin method in 5\% error rate with 64 respondents. Method of analytical descriptive, questionnaire technique, and correlation test were done to determine correlation between independent and dependent variable and path analysis model was done to understand the influence of independent variables to dependent variable both partially and simultaneously.

\section{RESULTS AND DISCUSSION}

Result of analysis showed that correlation between group dynamic variable (X) with empowerment variable (Y) is 0.651 which means the correlation between two variables is strong and direct. Contribution of group dynamic variable (X) is 42.40 $\%$. The $42.40 \%$ empowerment contribution is determined by group dynamic and the remaining $57.60 \%$ is determined by other external variable outside this research. Hypothesis test shows $\mathrm{Ho}$ is rejected and $\mathrm{Ha}$ is accepted because of significancy value (sig.) $0.000<0.05$ so it can be concluded that there is significant correlation between implementation of group dynamic variable with empowerment variable. It means that the higher empowerment intensity of group dynamic components in farmers group, the greater impact on empowerment effort output. Correlation between empowerment variable (Y) with learning independency of farmers in farming business variable $(Z)$ is 0.784 which means that correlation between two variables is strong and direct, $61.50 \%$ empowerment contribution to learning independency is determined by empowerment variable and the remaining $38.50 \%$ is determined by other external variable outside this research. Hypothesis test showed significancy value (sig.) $0.000<0.005$ and as result, Ho is rejected and Ha is accepted, so that it can be concluded that there is significant correlation between two variables, it means that the higher empowerment, the greater impact on learning independency of farmers in farming business. Correlation between group dynamic variable $(\mathrm{X})$ with learning independency variable $(\mathrm{Z})$ is 0.636 which means that the correlation between two variables is strong and direct. Contribution of group dynamic variable (X) to learning independency $(\mathrm{Z})$ is $39.20 \%$ which means that $39.20 \%$ independency contribution is determined by group dynamic, and the remaining $60.80 \%$ is determined by other external variable outside this research, hypothesis test shows significancy value (sig.) $0.000<0.05$, as result Ho is rejected and $\mathrm{Ha}$ is accepted, so that it can be concluded that there is significant correlation between two variables, it means the higher intensity of group dynamic, the greater impact on learning independency of farmers in farming business.

Path analysis model with SPSS version 13 proved that: (1) Influence of group dynamic variable (X) implementation to empowerment variable $(\mathrm{Y})$ is $(0.651) 2$ or equal to $42.40 \%$, and the remaining $(57.60 \%)$ empowerment variable is influenced by external variable outside this research, (2) Learning independency $(\mathrm{Z})$ is influenced by empowerment (Y) with value $(0.653) 2$ or equal to $42.64 \%$ and the remaining $57.36 \%$ is affected by other external variable outside this research, (3) Learning independency (Z) influenced directly by group dynamic $(X)$ implementation with value $(0.201) 2$ or equal to $4.04 \%$ and the remaining $95.96 \%$ is influenced by other external variable outside this research, and (4) Learning independency $(Z)$ influenced indirectly by empowerment of group dynamic $(\mathrm{X})$ with value $(0.26103) 2$ or equal to $39.20 \%$ and the remaining $60.80 \%$ is influenced by external variable outside this research.

The magnitudes of direct and indirect influence of empowerment subvariables that are learning dynamic (Y1), effort dynamic (Y2), and teamwork dynamic (Y3) to learning independency of farmers in farming business are (1) total 
influence of learning dynamic to learning independency of farmers in farming business is $37.60 \%$ (2) total influence of effort dynamic to learning independency of farmers in farming business is $2.86 \%$, (3) total influence of teamwork dynamic to learning independency of farmers in farming business is 14.90 $\%$ and (4) joint influence of learning, effort, and teamwork dynamic to learning independency of farmers in farming business is $55.36 \%$, the remaining $44.64 \%$ is influenced by other external variable outside this research.

Hypothesis test with t-test proved that partially learning dynamic variable (Y1), effort dynamic variable (Y2), and teamwork dynamic variable (Y3) influence significantly to learning independency of farmers in farming business (Z). Simultaneously, influence of independent variable to dependent variable is done by using $\mathrm{F}$ distribution, with assistance of SPSS 18.0 calculation it can be concluded that simultaneously there is significant influence between learning, effort, and teamwork dynamic to learning independency of farmers in farming business. The magnitude estimation result of three empowerment variables influence showed by $\mathrm{R}$ square value (R) 0.907. It means that the influence of learning, effort, and teamwork dynamic variable to learning independency development of farmers in farming business simultaneously is $90.70 \%$.

Empowerment of learning independency means provision of group power/strength and its member can reflect and evaluate causal factor that empower or enervate, identify their own potency and power for problem-solving solution, and able to empower group and its member while the counselor plays role as facilitator and partner to initiate lifelong learning implementation.

The importance of group empowerment for lifelong learning supported by K. Subrata (2000:17) who confirmed that group dynamic presents group power (dynamic interaction) of mutual learning and learning exchange in order to achieve group goals. Rahardjo (1996:169) confirmed that strategy to increase farmers community empowerment is through activation of farmers group institution as education unit, media, continuous learning strategy, and agent of change.

Wikinson (1997) comprehended group as a social field which has characteristics: (1) the presence of continuous social interaction, its social interaction dynamic indicates meaningful life in group, (2) the presence of change direction to a certain point, and (3) the presence of change or development that take place regularly on the elements and formation structure. Because of group is a social field, it has to be understood and interpreted as an arena where influence and power work regularly and coordinatively, which finally produces commmunity changes. By understanding concept and characteristic of group, it can be understood that group concept is viewed as "living" organism (a systemic unity) and can be formed and developed (check study of Bell and Newby, 2008). Margono Slamet $(200,14)$ confirmed further that the strengthening of group role must be directed to empowerment and development of independency, so that a group must be understood not only as social field but also as educational unit, agent of change, and media of lifelong learning strategy, because educative interaction among individuals in group is becoming power or movement that is able to change attitude and behaviour of farmers to a higher level (better farming, better business, and better living). This assumption is powered by various study of "community power" that place social group and organization in certain place and capacity so that people are able to do activity of social processes, such as interaction between each other to learn and cooperate, compete, ally, even to conflict internally and between group, this interaction process in turn becomes dynamic of group or community.

The thought strengthen assumption that group is viewed as effective way and approach in farmers empowerment effort to learning independency, because a group basically has dynamic, the difference is on the level, one group might has higher dynamic than the other or conversely, according to Beal et al. (1982) and Cartwright and Zender (1968) in K. Subrata (2000:20), group dynamic is science that examines the life of group i.e. analyze ways of organizing, managing, and decision making in group. Related with that, Margono Slamet (2005:54) explained conclusion of experts such as Homans (1985) who interpreted group dynamic by emphasizing social relation analysis in group based on principle that group behaviour is a dynamic interaction result between members. Research conclusion of Bradford et al. (1984) proved that through group dynamic someone will be able to change his/her conception and attitude or to be changed because there is interaction between members. Bonner (1983) suggested that group dynamic is manifested by components that caused group to life, move, active, and effective in achieving productive goal. To learn group dynamic, it is needed to learn group dynamic components as group driver power so that the group becomes dynamic and productive as stated by K. Subrata (2000) and Slamet (2005), components that referred are: (1) group goal, (2) group structure, (3) group function, (4) group development, (5) group harmony, (6) group atmosphere, (7) group pressure, and (6) group effectivity.

Kindervatter (1989:13) viewed empowerment as a process to stimulate individual or group of community to get comprehension and control to social, economical, and political power in order to improve life status in community. Empowerment is related with ability or process to make individual or group of people or community is able to understand and control social, economical, and political situation that develop in their environment. So, empowerment is an effort to know, understand policy and utilize power, to investigate processes that enable community to control their life, skill, and position, to become a critical and effective member of community, and also to change the power. Empowerment reflects importance of emancipatory that encourages people to participate collectively in development and engage individual or community in enlightenment, to be aware of collective organization so that they can participate, develop democratization, and to create culture of teamwork based on mutual respect as strong foundation to continuous development.

Strengthen of group dynamic component for lifelong learning and empowerment addressed for giving strategic role to member and group and for identifying collective power to strengthen information access, awareness and participation, insitutional capacity, responsibility, social capital, creativity, 
fighting power, care, inovativeness, critical power, and evaluation (control) power in decision making of social, economical, and political problem solving in their life.

Strengthening of group role has recognized that it was able to drive change and improvement of counseling implementation system, social, economical, and political condition of individual, group, or community. Wilkinson (1982) confirmed that empowerment is change (progress) that is done or developed purposively by members of community. They formulate the problem, write working plan, and determine direction of change according to their own belief and perception and the change is believed as an improvement. The statement confirmed by Glickman (1989) in Robinson (1994) that empowerment is a process to increase power and ability in oneself, such as competency and creativity through internal control in acting and solving problems independently.

Strengthening of group role through empowerment has proved its ability to change attitude and behaviour of farmers. Change in learning dynamic dimension manifestated as: engagement and activity of farmers to increase knowledge, attitude, and skills in following various counseling activity, strong encouragement of farmers to understand various information and learning material from various media that support new knowledge, attitude, and comprehension about reason of accepting and using innovation, and skill in managing business output. Effort dynamic dimension manifestated by more innovative attitude and behaviour of farming business production (pre-harvest, post-harvest, and product marketing) and ability to utilize business opportunity to achieve economical scale, production improvement, and product marketing. Change of teamwork dimension manifestated by activity and teamwork spirit with shared decision, openness, and mutual respect principle in designing and implementing process of improvement and change participatively in economical, social, cultural, and environmental sector.

Strengthening of group dynamic and empowerment has proved its correlation and contribution to learning independency development of farmers in farming business which showed by attitudes and behaviours: (1) aware of problem faced and has strong motivation to overcome through learning, (2) fighting power in achieving aspiration and goal, 3) rational thinking ability, (4) openness to accept and apply innovation (innovative), 5) full of iniative to do learning act (creative), 6) future knowledge, (8) openness attitude in learning together with members, groups, and other parties (participative) in various learning programmes, (9) develop entrepreneurial spirit, respect and utilize time to learn continuously, and prioritize output and quality, and (10) selfrespect.

\section{CONCLUSION}

- Strengthening of group dynamic components role supports implementation of empowerment programme, it can be seen from strong and direct correlation characteristic between group dynamic variable and empowerment variable and significant direct influence.
- Group dynamic has strong and direct correlation with learning independency of farmers in farming business. It is also giving explanation that group dynamic has significant influence both directly and indirectly (through empowerment variable)

- Empowerment has strong and direct correlation with learning independency of farmers in farming business and shows that empowerment variable has direct significant influence to learning independency of farmers in farming business variable.

- Empowerment subvariables that are learning, effort, and teamwork dynamic have strong and direct correlation with learning independency development of farmers in farming business.

- Empowerment subvariables that are learning, effort, and teamwork dynamic have significant influence both partially and simultaneously

- Research findings proved that development of continuous learning independency or education to community can be done through strengthening of group role as learning media and strategy.

\section{REFERENCES}

[1] Abbas Syamsuddin. (1995). Sembilan Puluh Tahun Penyuluhan Pertanian di Indonesia (Lokarya). Kerjasama Badan Penelitian dan Pengembangan Pertanian dengan Cornel Internasional.

[2] Ace Suryadi. (2014). Model Pengelolaan Belajar Sepanjang Hayat Dalam Pemberdayaan Masyarakat. (Prosiding Seminar Nasional : Penguatan Peran Pendidikan Luar Sekolah Dalam Pembangunan Masyarakat). UPI Bandung

[3] Adjid D Abdulmadjid. (2001). Dasar-dasar Pembinaan Kelompok Tani dalam Intensifikasi Pangan. Jakarta. Satuan Pengendalian Bimas.

[4] Barker, LL, KJ. Wahlers, KW Watson dan RJ. Kibler. (1987). Group in Process ; And Interdiction to Small Group Communication Prentice Hall. New Jersey. Inc Engglewood. Cliff.

[5] Beal, George M, Joe M, Bohlen dan Neil J. Raudabugh. (1992). Leadership and Dynamic Group Action. Ames Lowa USA. The Lowa State University Press.

[6] Cartwrigh, A Zander. (1968). Group Dynamic Research and Theory. New York. Happesand Published.

[7] Castro, C. J. (2004). Sustainable Development, Mainstream and Critical Perspective Organization, Organization and Environment.

[8] Darmawan, A. H. (2000). Poverty: Powerlesness, and Poor People Empowerment, Elliot, J.T, 1996, An Introduction to Sustainable Development. London and New York. The Developing word, Routledge.

[9] Departemen Pertanian RI. (2002). Proyek Peningkatan Pendapatan Petani Kecil (P4K). Jakarta. Deptan.

[10] Fear, F.A and Schwarzweller,H.K. (1985). Introduction : Rural Sosiolog. Greenwich and London. Community and Community Development. JAL.

[11] Freire P. (1983). Education For Critical Consiousness. New York. The Seabury Press.

[12] Harry Hikmat. (2001). Strategi Pemberdayaan Masyarakat. Bandung. Humaniora Utama.

[13] Jermie M, Yunus (1994). Sistem Penyuluhan Pertanian Pembangunan di Indonesia. PPs IPB Bogor. (Desertasi).

[14] Jhon Wong (1989). Group Farming in Asia; Exverience and Potentials. Singapore University Press. 
[15] Joni Rahmat (2013). Belajar Sepanjang Hayat. Bandung. Edukasia Press

[16] Kartasapoetra G. (1988). Teknologi Penyuluhan Pertanian. Jakarta. Bina Aksara.

[17] . (2004). Budidaya Tanaman Berkhasiat. Jakarta. Rineka Cipta.

[18] Kartasasmita. (1995). Pembangunan Untuk Rakyat, Memadukan Pertumbuhan dan Pemerataan. Jakarta. Cides.

[19] Kindervatter S. (1989). Non Formal Education As an Empowering Process. Amherst. Massachussets ; Centre for International Education University of Massachussets

[20] . (1997). Non Formal Education As an Empowering Process. Unprinted in United States of America.

[21] K. Subrata. (2000). Dinamika Kelompok dan Kepemimpinan. Bandung.

[22] Margono Slamet. (2005). Dinamika Kelompok, Kepemimpinan dan Organisasi. PPs IPB Bogor.

[23] Sudjana. (1996). Pendidikan Luar Sekolah. Wawasan Sejarah Perkembangan, Falsafah dan Teori Pendukung Asas. Bandung. Nusantara Press. 